\title{
The Effects of Money Laundering on Monetary Markets
}

\author{
Dr. Marwan Mohammad Aboel-Majeed Abu-Orabi ${ }^{1} \&$ Dr. Abeer F.A. Al Abbadi ${ }^{1}$ \\ ${ }^{1}$ Department of Finance and Banking, Faculty of Business and Finance, The World Islamic Sciences and \\ Education University, Jordan- Amman \\ Correspondence: Dr. Marwan Mohammad Aboel-Majeed Abu-Orabi, Department of Finance and Banking, \\ Faculty of Business and Finance, The World Islamic Sciences and Education University, Jordan- Amman \\ (11623), P.O Box 14. E-mail: abeer_abadei@yahoo.com
}

Received: October 22, 2019

doi:10.5539/mas.v13n12p43

\author{
Accepted: November 24, 2019 Online Published: November 25, 2019 \\ URL: https://doi.org/10.5539/mas.v13n12p43
}

\begin{abstract}
The aim of this study is to determine the impact of money laundering on: the competition in the financial and monetary markets, the stability of the investment sector in Jordan, the ability of the government to control the monetary policies in Jordan, the attraction of foreign investments to the markets in Jordan and the Jordanian dinar exchange rates. A survey of the components and sample of the study population, composed of employees of the Central Bank of Jordan and the Audit Bureau, was used. A questionnaire was developed as a tool for the study, distributed to the study sample of (35).

The study concludes that: Money laundering has a massive effect on monetary markets, competition in the financial and monetary markets, the government's capability to control monetary policies, the investment sector's stability, attracting foreign investments for the marketplace, and Jordanian Dinar's exchange rate. Depending on the results of the study, the researcher recommends Introducing laws and regulations to combat money laundering, fostering the role judicial authorities, empowering prohibiting and punishment of involved financial institutions, confiscating of funds, punishing perpetrators, and developing legal procedures that regulate banks', financial institutions' and companies' activities.
\end{abstract}

Keywords: money laundering, monetary markets, financial markets

\section{Introduction}

Money laundering is a financial crime that might affect negatively on the economic stability, especially on finance and investments leading to monetary markets (Jack Law Group, 2013); it can be said that money laundering is concealing the source, the nature, the place and the disposal of funds and assets that are acquired through illegal or criminal activities such as embezzlement, drug dealing, prostitution, corruption, and largescale criminality. It's a process through which illicit funds, that resulted from criminal activities transferred into assets, that can't be traced back to its illegal origins, via legitimate businesses. Recently, money laundering has acquired significant recognition as a global trend.

According to Boles (2017), money laundering is conducting a series of transactions using illegal and illicit funds in order to appear as if it's legal and licit, which means concealing and hiding the source of illegal funds through consecutive transfers that ultimately appear as legal funds. Money laundering, as defined in the Dictionary of Finance and Banking (2008), is the process where the money is acquired illegally, either through stealing, drug dealing or so forth, in which it appears as if it's from legal sources.

Furthermore, money laundering can be described as the process of transferring illegal money into legal money using high-ranking officials in large corporations, to transfer the funds either through personal accounts, tax evasion, prostitution or drug dealing. One of the most used methods of money laundering is via using financial organizations and companies, which act as a front for receiving illicit money (https://twitter.com/ WorldCompliance/2013).

Statistics, issued by the United Nations office in Drugs and Crime, reveal the volume of illegal funds acquired through drug dealing and organized crimes, and investigate the extent of laundering such funds, where the report estimates that criminal funds reached \%3.6 of global GDP in 2009, with the laundering of \%2.7 (or $\$ 1.6$ trillion US dollar). Statistics show that over 1200 new anti-money-laundering (AML) facilities were established between 2009 and 2010, and the global market currently is worth $\$ 450$ million dollars, it will grow at an average 
annual compound rate of $\% 9$ over the next few years (Boles, 2017).

The success of money laundering operations has far-reaching consequences on financial systems as a whole in many developing countries. One of these consequences is losing control of the national economic policy, since illicit capital, originating from money laundering activities and other economic and financial crimes, could undermine government budgets and destabilize local markets (Aluko, 2012).

In addition, money laundering impacts the financial behavior and macroeconomic performance in various ways, such as public policy mistakes, caused by measurement errors in the national accounts statistics, exchange rates' volatility and interest rates because of unexpected transfer of funds through borders. Also, the threat of monetary stability due to improper structures of assets, the effects on tax collection and allocation of public expenditures owing to incorrect reporting of income, misallocation of resources because of distortions in asset prices and essential goods, and the impact of corruption on legal transactions due to perceived possibility of association with crime. Accordingly, illicit incomes, originating from criminal enterprises, undermine government budgets in some developing countries, which lead to losing control over its economic policy.

\section{Study Problem}

It is difficult to list the effects of money laundering on the economic development and monetary markets, but it is clear that such activity could jeopardize financial sector institutions, which are considered the main pillars of economic growth, thereby reducing the productivity of the real sector of economy by the diversion of resources and fostering crime and corruption, thus slowing down the economic growth (Idowu and Obasan, 2012).

The problem of this study lies in answering the following key question:

What is the effect of money laundering on Monetary Markets in Jordan?

1. What is the effect of money laundering on competition in the financial and monetary markets in Jordan?

2. What is the effect of money laundering on the government's capability to control monetary policies in Jordan?

3. What is the effect of money laundering on the investment sector's stability in Jordan?

4. What is the effect of money laundering on attracting foreign investments for the marketplace in Jordan?

5. What is the effect of money laundering on the Jordanian Dinar's exchange rate?

\section{Study Objectives}

This study aims, primarily, to determine the effect of money laundering on monetary markets in Jordan. Branching from the primary objective are the following subsidiary objectives:

1. Determining the effect of money laundering on competition in the financial and monetary markets in Jordan.

2. Determining the effect of money laundering on the government's capability to control monetary policies in Jordan.

3. Determining the effect of money laundering on the investment sector's stability in Jordan.

4. Determining the effect of money laundering on attracting foreign investments for the marketplace in Jordan.

5. Determining the effect of money laundering on the Jordanian Dinar's exchange rate.

\section{Study Importance}

The importance of this study lies in encouraging financing investments and protecting them from money laundering by combating money laundering, which involves combating terrorist financing, drug dealing, arms trade, funds from bribery, abuse of public offices and committees, and black market trading.

Furthermore, it lies in the potential benefits of its outcomes for various economic sectors, especially the financial sector. It will expand the scope of ethics related to economic impacts of money laundering in Jordan, thus helping relevant authorities in developing new policies for combating money laundering to curb money laundering in Jordan.

\section{Study Hypotheses}

Based on the problem of the study and its question, the following hypotheses have been formulated: 
Main hypotheses H0: There's no sign of a statistical indicator at the level of $(\alpha \leq 0.05)$ for money laundering on monetary markets in Jordan.

Branching from the previous hypothesis are the following subsidiary hypothesis:

1. H01: There's no sign of a statistical indicator at the level of $(\alpha \leq 0.05)$ for money laundering on competition in the financial and monetary markets in Jordan.

2. H02: There's no sign of a statistical indicator at the level of $(\alpha \leq 0.05)$ for money laundering on the government's capability to control monetary policies in Jordan.

3. H03: There's no sign of a statistical indicator at the level of $(\alpha \leq 0.05)$ for money laundering on the investment sector's stability in Jordan.

4. H04: There's no sign of a statistical indicator at the level of $(\alpha \leq 0.05)$ for money laundering on attracting foreign investments for the marketplace in Jordan.

5. H05: There's no sign of a statistical indicator at the level of $(\alpha \leq 0.05)$ for money laundering on the Jordanian Dinar's exchange rates.

\section{Study Module}

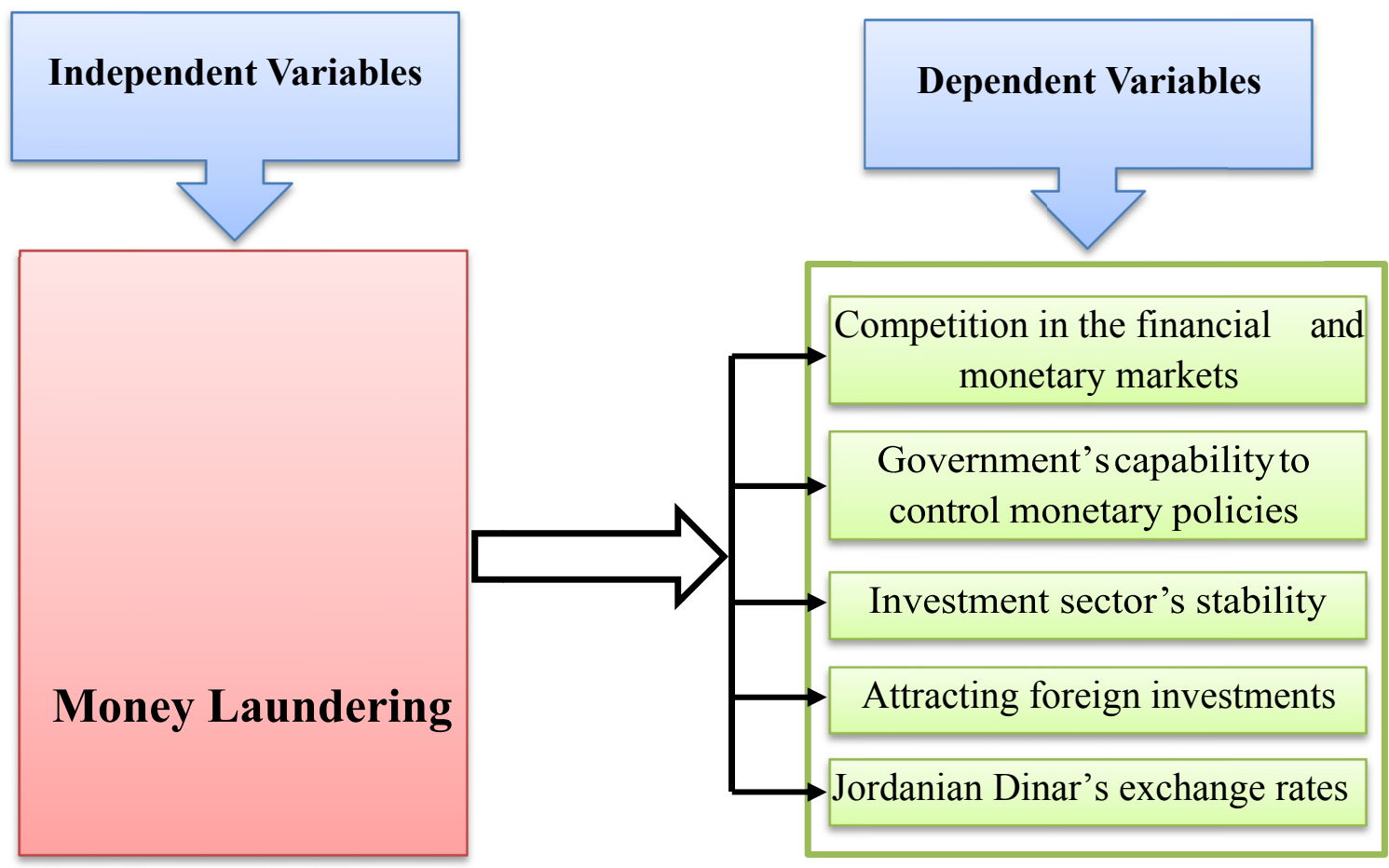

Module (1) prepared by the researcher based on the studies (Sagastume, et al., 2016; Conyers and Pearman, 2013; Aluko, 2012; Ayodegi and Mahmoud, 2012)

\subsection{Economic Distortions and Investment Instability}

Money launderers, while trying to conceal the source of their illicit proceeds, transfer the proceeds from an economic enterprise to another with no valid economic reasons. Since there is no motivation to generate revenues, money launderers, in most cases, invest their illicit proceeds in economic and commercial enterprises, that don't essentially benefit the country's economy, in which these proceeds exist in. When making investment decisions, money launderers pay high premiums on investments that will allow protection from suspicion of illicit proceeds. In other words, money launderers don't necessarily go after generating high revenues of generated investments but rather after investments that simply allow the recirculation of their illicit proceeds even if it entails a low income rate (Ayodegi and Mahmoud, 2012). Consequently, the case, in which money recirculation is involved, increases in countries that produce higher revenue rates than in those with poor economic policies and low revenue rates, resulting in the violation of economic law. Moreover, large capital flows or local outflows have highlighted that money laundering is likely to negatively impact exchange and 
interest rates, leading to a fundamental impact on the special assets process in which the capital is invested in (Sagastume, et al., 2016).

With exchange rate remaining volatile without hindrance, the massive flows of capital to a given country results in the acknowledgement and the expansion of the funds base for that country caused by the inflow of capital, which leads to the increase demand on domestic funds by monetary authorities of affected countries (Tanzi, 1996). Furthermore, the inflation in exchange rate leads to the case where traditional export loses competitiveness of imports, while local prices increase due to the pressure of monetary bases for countries. At this point, economic policy makers in countries will head to financial policy tightening to create a budget surplus so it could be used to address the consequential financial impacts on flows of capital (Blotevogel, 2015).

Idowu (2012) states that capital flows and investments abroad will lead to weak impacts on the international financial markets due to its comprehensive nature. Hence, this kind of distortion means that financial difficulties resulting from a single financial center can spread easily to other financial markets, thus impeding the economic growth and creating a financial instability.

\subsection{Literature Review}

According to John and Gary (2001), one of the impacts of money laundering and currency maneuvering is the undermining of currencies and interest rates, often adversely, in Jordan's case, which relies on the acquisition of other currencies to comply with its international obligations and to meet its local needs, then money laundering impacts negatively on currencies and interest rates by reinvesting funds where the schemes should be secure to some degree of doubt in terms of larger return rates. Since profitability isn't a catalyst for investing criminal economical proceeds in any business (Ayodegi and Mahmoud, 2012), it is therefore always appropriate for money launderers to move around their proceeds depending on what the situation may require, then, the economical explanation is that moving the ill-founded proceeds creates unexplainable changes in monetary demands and increases the instability of international capital flows, interest and exchange rates (Sagastume, et al., 2016). On the other hand, this is the situation that works towards establishing and implementing appropriate national economic policies.

The private sector is also affected by one of the most serious impacts of money laundering on microeconomic, particularly in developing countries, where money launderers use private companies, for collecting their proceeds of illegal activities with legal funds, to conceal their illicit proceeds. Thanks to the possibility of acquiring large amounts of illegal funds, these companies can support their products and services at a very lower level than market pricing, and in some cases, they offer products with prices lower than the production cost of manufacturers (Jeffery, 2015). Therefore, these companies usually have a competitive advantage over the legal manufacturing companies that attracts capital from financial markets, which makes it difficult, if not impossible, for legit commercial businesses to compete against companies used by money launderers. It is clear that the principles of running such criminal institutions do not comply with traditional open market principles of legit commercial businesses, resulting in more negative impacts on macroeconomic (Ayodegi and Mahmoud, 2012).

Sagastume, et al. (2016) has conducted a study, which reviews the status quo of money laundering and terrorist funding, and sheds light on the importance of preventing them in order to achieve economic and financial stability in Latin America and the Caribbean. Furthermore, it reviews the compliance of Latin America's and the Caribbean countries with the recommendations of the financial procedures task force, and it analyzes the regions performance regarding the effects of money laundering on national economies. The study has also shown the presence of a crucial and negative moral impact of money laundering on the national economy, inflation and exchange rates. In addition, studying the case in Mexico provides a defined vision to rehabilitate the country and its policies to combat these operational risks on the financial sector.

The study of Conyers and Pearman (2013) has also presented that money laundering has a significant impact on the national income, and it affects foreign investments. In addition, the study has referred to the role of antimoney-laundering legislations in preventing money laundering. Moreover, it showed that the government could curb money laundering through tax policies, an efficient bank records' system and spreading awareness in the nation's via media.

Aluko (2012) has conducted a study regarding the impact of money laundering on investment financing, and found that money laundering and financial crimes have a negative impact economic growth and financial stability. Therefore, what is required of countries is working hand in hand to reduce the negative impacts related to investment financing and nw jobs and technologies. It also found a positive correlation between corruption and money laundering in most countries. 
In another study, conducted by Idowu (2012), shows that money laundering has adverse consequences on financing investments. Hence, affecting the government's revenue, economic growth rate and threatening the political stability and homeland security for the nation. Therefore, the study recommends the importance of verifying the financial institutions' activities since it plays a crucial role in investment financing for different countries.

Ayodegi and Mahmoud (2012) have found effects of money laundering on economic growth and financial stability. Given that financial institutions play a crucial role in investment financing, therefore, it requires them to combat money laundering by verifying opening accounts, accepting funds and giving loans. Thus, the study recommends the submission of information to prevent money laundering, financial crimes and terrorist funding.

Kumar (2012) study Money Laundering: Concept, Significance and its Impact shows financial sector may get negative effects of money laundering especially financial institutions and its effect in two ways there seems to be correlation between money laundering and fraudulent activities undertaken by employees of the institutions, leads to strengthens the criminals and other parallel system of money laundering channels, and fraud and corruption is an obstacle to Customer trust to the growth of sound financial institutions.

Lucian (2012) study The Concept of Money Laundering in Global Economy, shows Although money laundering market was valued at $\$ 600$ billion, i.e. between 2 and $5 \%$ of global GDP, the new movement of capital boosts the activity of transnational crime whose lack in national character hinders the possibilities of repression. and the fight against the money laundering process requires specific national regulations which must be integrated in the international cooperation process..

Al-Shaher (2009) Money Laundry and its Effect on the Economics of the Developing Countries shows that Money Laundering contributes and to deepening disparities in income distribution, Leads to Increase the supply of the national currency against the demand for foreign currencies. Domestic savings fail to meet the investment requirements needed to increase the economic growth rates as a tendency of a large part for dirty Money to foreign banks. Money-laundering effects on the stability of financial markets in many countries, especially emerging capital markets, leads to markets collapse.

\section{Study Methodology}

Field survey has been used for the elements of the study and its sample, consisting of workers in the Central Bank of Jordan and Court of Audit. A questionnaire has been developed as a tool for this study, and a descriptive associative approach has been used for dealing with classification of some data, to describe the elements and sample of the subjects under study, for obtaining the results of the Zero-hypotheses proposed in this study.

To achieve the current objectives of the study, reliance has been placed on two-tier resources:

- Primary Sources: The using of a questionnaire as a main tool for collecting data directly of sample members' answers, which contains a number of points measuring the impact of money laundering on monetary markets.

- Secondary Sources: Conducted by returning to books, resources, Arab and foreign references, reports, periodical articles, researches and previous studies that have addressed the subject of this study, and searching and reading off of internet websites to prepare and frame theoretical hypotheses concerning this study.

\section{Study Sample}

The study sample consists of workers in the Central Bank of Jordan and Court of Audit, numbering (257), (87) questionnaires have been distributed to a sample of workers in the Central Bank of Jordan and Court of Audit, (47) have been recovered, and only (35) of them were valid for statistical analysis.

Shown in table 1 are the distributions of the averages on the weights of responses.

Table 1. The distributions of the averages on the weights of responses

\begin{tabular}{cccc}
\hline & Low & Medium & High \\
\hline Range & $1.00-$ less than 2.33 & $2.33-$ less than 3.66 & $3.66-5.00$ \\
\hline
\end{tabular}

\section{Study Tool Stability}

The stability of the questionnaire has been validated depending on Cronbach's alpha factor: to check internal cohesion and the extent to which each point relates to its field, through extracting the value of this factor for 
each point in this questionnaire and the extent to which each point relates to its field.

Table 2. Internal cohesion factor

\begin{tabular}{ccc}
\hline Number & Dimension & Alpha's value \\
\hline $\mathbf{1}$ & Competition in the financial and monetary markets & 0.906 \\
$\mathbf{2}$ & Government'scapability tocontrolmonetary policies & 0.887 \\
$\mathbf{3}$ & Investment sector's stability & 0.912 \\
$\mathbf{4}$ & Attracting foreign investments & 0.924 \\
$\mathbf{5}$ & Jordanian Dinar's exchange rates & 0.930 \\
$\mathbf{6}$ & All Dimensions & 0.963 \\
\hline
\end{tabular}

We notice the values of Cronbach's alpha factor for internal cohesion to all dimensions of the study ranged between $(0.887-0.930)$, and the value of the cohesion factor of all dimensions was $(0.963)$, thus all values are greater than (0.60), which is an indicator of cohesion for all dimensions of this study, and credibility of the tool of the study and reliability for conducting statistical analysis.

\section{Adopted Means of Statistics}

The answers of all sample members have been entered as data through Statistical Package for the Social Science program after obtaining it from the questionnaires that have been recovered after distribution. The data has been processed depending on the test that meets the purpose of this study, in which the following methods have been adopted:

- Cronbach's alpha test: to measure the reliability and credibility of the tool in collecting data used to measure the variables contained in this study.

- Measures of central tendency, such as arithmetic mean, the median and the mode: to describe the answers of the sample to the questions of the tool about the variables and dimensions of this study. As well as measures of dispersion (standard deviation, variance) to demonstrate the extent of dispersion of the answers and their deviation from the arithmetic mean.

- The analysis of simple and multiple linear regression: to measure the impact of independent and dependent variables.

\section{Statistical Analysis and Results of the Study}

This section addresses the results of the study, by displaying the responses of the sample members to the questions of the study, and processing them statistically using statistical methods, eventually obtaining results, analyzing and explaining them.

\subsection{Firstly: Results of Testing the Main Hypotheses}

Before testing hypothesis, arithmetic means and standard deviations are calculated to the extent of the impact of money laundering on monetary markets in Jordan consisting of (competition in the financial and monetary markets, the government's capability to control monetary policies, the investment sector's stability, attracting foreign investments for the marketplace, the Jordanian Dinar's exchange rate). Table 3 demonstrates that.

Table 3. arithmetic means and standard deviations are calculated to the extent of the impact of money laundering on monetary markets in Jordan

\begin{tabular}{cccccc}
\hline No. & Dimension & $\begin{array}{c}\text { Arithmetic } \\
\text { mean }\end{array}$ & $\begin{array}{c}\text { Standard } \\
\text { deviation }\end{array}$ & Rank & Level \\
\hline $\mathbf{1}$ & $\begin{array}{c}\text { Competition in the financial and } \\
\text { monetary markets }\end{array}$ & 3.715 & 0.491 & 1 & High \\
& $\begin{array}{c}\text { Government's capability to control } \\
\text { monetary policies }\end{array}$ & 3.055 & 0.580 & 5 & Medium \\
$\mathbf{3}$ & Investment sector's stability & 3.662 & 0.317 & 3 & High \\
$\mathbf{4}$ & Attracting foreign investments & 3.667 & 0.484 & 2 & High \\
$\mathbf{5}$ & Jordanian Dinar's exchange rates & 3.441 & 0.520 & 4 & Medium \\
& Total Score & 3.508 & 0.217 & & Medium \\
\hline
\end{tabular}


Shown in table 3 that the arithmetic mean of competition in the financial and monetary markets has reached (3.715) with a very high relative importance, thus becoming the number one dimension affected by money laundering in Jordan. Whereas the arithmetic mean of government's capability to control monetary policies has reached (3.055) with a medium relative importance, thus becoming the last dimension. Moreover, the total score has reached (3.508) with a medium relative importance.

\subsection{Testing Study Hypotheses}

H0: There's no sign of a statistical indicator at the level of $(\alpha \leq 0.05)$ for money laundering on monetary markets in Jordan.

To test the main hypotheses, the multiple linear regression has been used, and the table 4 demonstrates it.

Table 4 shows the results of money laundering on monetary markets in Jordan consisting of (competition in the financial and monetary markets, the government's capability to control monetary policies, the investment sector's stability, attracting foreign investments for the marketplace, the Jordanian Dinar's exchange rate)

\begin{tabular}{|c|c|c|c|c|c|c|c|c|c|}
\hline \multicolumn{5}{|c|}{ Coefficients } & \multicolumn{2}{|c|}{ ANOVA } & \multicolumn{2}{|c|}{$\begin{array}{c}\text { Model } \\
\text { Summery }\end{array}$} & \multirow[t]{2}{*}{$\begin{array}{c}\text { dependent } \\
\text { variable }\end{array}$} \\
\hline Sig $t$ & $\mathrm{~T}$ & $\begin{array}{l}\text { Standard } \\
\text { error }\end{array}$ & B & dimension & $\mathrm{F}$ & Sig F & $\mathrm{R}^{2}$ & $\begin{array}{c}\text { Adjuste } \\
\mathrm{d} \\
\mathrm{R}^{2}\end{array}$ & \\
\hline 0.048 & 2.010 & 0.488 & 0.989 & $\begin{array}{l}\text { Competition in the } \\
\text { financial and } \\
\text { monetary markets }\end{array}$ & & & & & \\
\hline 0.000 & 5.000 & 0.765 & 3.824 & $\begin{array}{c}\text { Government's } \\
\text { capability to control } \\
\text { monetary policies }\end{array}$ & 19.092 & 0.000 & 0.778 & 0.760 & $\begin{array}{c}\text { Money } \\
\text { laundering }\end{array}$ \\
\hline 0.000 & 5.419 & 0.656 & 3.555 & $\begin{array}{l}\text { Investment sector's } \\
\text { stability }\end{array}$ & & & & & \\
\hline 0.000 & 3.978 & 0.747 & 2.971 & $\begin{array}{l}\text { Attracting foreign } \\
\text { investments }\end{array}$ & & & & & \\
\hline 0.000 & 20.164 & 0.058 & 1.170 & $\begin{array}{l}\text { Jordanian Dinar's } \\
\text { exchange rates }\end{array}$ & & & & & \\
\hline
\end{tabular}

* a statistical indicator is at the level of $(\alpha \leq 0.05)$

The above table indicates the relation of dependent and independent variable (money laundering) statistical sign, where the value of calculated F was (19.092), with an indicator level of ( $\operatorname{Sig} F=0.000)$ which is less than $(0.05)$. Also, the value of the determination coefficient was $\left(\mathrm{R}^{2}=0.778\right)$, which indicates that $(\% 77.8)$ of the variance for the independent variables altogether (competition in the financial and monetary markets, the government's capability to control monetary policies, the investment sector's stability, attracting foreign investments for the marketplace, the Jordanian Dinar's exchange rate) can be explained through the variance of the module variables, with maintaining all other variables stable.

As for the regression coefficient $(\mathrm{B}=0.980)$, it indicates the impact on competition in the financial and monetary markets, which is a semantic impact, where the value of $\mathrm{t}$ was (2.010) with an indicator level of ( $\mathrm{Sig}=$ 0.048). Also, the value of regression coefficient for the government's capability to control monetary policies (B $=3.824)$, which shows the impact for this variable, which is a semantic impact, where the value of $t$ was (5.000) with an indicator level of $(\mathrm{Sig}=0.000)$. However, the value of regression coefficient for the investment sector's stability $(\mathrm{B}=3.555)$, which shows the impact for this variable, which is a semantic impact, where the value of $\mathrm{t}$ was (5.419) with an indicator level of $(\mathrm{Sig}=0.000)$. As for the value of regression coefficient for the Jordanian Dinar's exchange rate $(B=1.170)$, which shows the impact for this variable, which is a semantic impact, where the value of $\mathrm{t}$ was (20.164) with an indicator level of $(\mathrm{Sig}=0.000)$.

Based on that, we reject the main hypotheses H0: There's no sign of a statistical indicator at the level of ( $\alpha \leq$ 0.05 ) for money laundering on monetary markets in Jordan. And we accept the alternative hypothesis "There is a sign of a statistical indicator at the level of $(\alpha \leq 0.05)$ for money laundering on monetary markets in Jordan." 


\section{Conclusions and Recommendations}

Money laundering is considered a global trend, it imposed itself in the past few years as an economical crime, where money launderers aim to conceal the illicit origin of their proceeds. Regarding, the effects of this phenomenon on Jordan, from the analysis of the responses of the sample members of this study, we can conclude the following:

1. Money laundering has a massive effect on monetary markets.

2. Money laundering has an effect on competition in the financial and monetary markets.

3. Money laundering has an effect on the government's capability to control monetary policies.

4. Money laundering has an effect on the investment sector's stability.

5. Money laundering has an effect on attracting foreign investments for the marketplace.

6. Money laundering has an effect on the Jordanian Dinar's exchange rate.

Depending on the results of the study, the researcher recommends the following:

1. Introducing laws and regulations to combat money laundering, fostering the role judicial authorities, empowering prohibiting and punishment of involved financial institutions, confiscating of funds, punishing perpetrators, and developing legal procedures that regulate banks', financial institutions' and companies' activities.

2. In financial and regulatory terms of banks, the study recommends the development of the financial control, by the Central Bank of Jordan and the other relevant authorities, for the banks' and companies' activities, ensuring the implementation of the law, monitoring the financial inflows and outflows, and observing the circulation of illicit funds by developing up-to-date working mechanisms involving transparency of the capital sources.

\section{References}

Al-Shaher, Shaher. (2009). Money Laundry and its Effect on the Economics of the Developing Countries. Rafidain Magazine, 94(31). https://doi.org/10.5539/ijef.v6n3p227

Aluko, Ayodegi. (2012). The Impact of Money Laundering on Economic, and Financial Stability and on Political Development of Developing Countries. International Corporate Governance, Financial Regulation and Economic Law (ICGFREL), Institute of Advanced Legal Studies School of Advanced Study University of London. https://doi.org/10.1108/13685201211266024

Ayodeji, A., \& Mahmood, B. (2012). The impact of money laundering on economic and financial stability and on political development in developing countries: The case of Nigeria. Journal of Money Laundering Control, 15(4), 442-457. https://doi.org/10.1108/13685201211266024

Blotevogel, R., (2015). The Productivity Challenge in Iran. IMF Country Report No.15/350 (Washington: International Monetary Fund).

Boles Jeffrey R.. (2017). Anti-Money Laundering Initiatives for the South African Real Estate Market. Journal of Comparative Urban Law and Policy, 1(1). Study Space IX Cape Town, South Africa A. Available at: https://readingroom.law.gsu.edu/jculp/voll/iss $1 / 14$

Conyers, D., \& Pearman. (2013). Impact of new bermuda anti-money laundering regime on investment fund operators and managers. Retrieved from http://www.conyersdill.com/publicationfiles/

Idowu, A. (2012). Anti-money laundering policy and its effects on bank performance on Nigeria Dept. of Management and Accounting Faculty of Management Sciences. Retrieved from http://www.saycocorporativo.com/saycoUK/BIJ/journal/Vol5No2/Article_19.pdf

Jack Law Group, PC. (2013). Anti-money laundering regulations on the horizine for investment adviser, curities and corporation counsel.

Jeffrey R. Boles. (2015). Financial Sector Executives as Targets for Money Laundering Liability, 52 AM. BUS. L.J. 365, 368. https://doi.org/10.1111/ablj.12049

Kumar, Vandana Ajay. (2012). Money Laundering: Concept, Significance and its Impact. European Journal of Business and Management, 4 (2), 113-119.

Rădulescu, Dragoş Lucian. (2010). The Concept of Money Laundering in Global. International Journal of Trade, Economics and Finance, 1(4), 354-360. https://doi.org/10.7763/IJTEF.2010.V1.63 
Sagastume Willy Zapata, Juan Carlos Moreno-Brid and Stefanie Garry. (2016). Money Laundering and Financial Risk Management in Latin America, with Special Reference to Mexico. Economía: teoria y práctica $・$ Nueva Época, número 44, enero-junio. 9-50. http://www.izt.uam.mx/economiatyp/ojs

Tanzi, V. (1996). Money laundering and the international system. International Monetary Fund, Working Paper. Retrieved from http://www.imf.org/external/pubs/cat/longres.cfm?sk=2029.0

Walker, John. (2007). Measuring Global Money Laundering, Paper presented at the conference Tackling Money Laundering. University of Utrecht, Utrecht, Netherlands, November 2007.

\section{Copyrights}

Copyright for this article is retained by the author(s), with first publication rights granted to the journal.

This is an open-access article distributed under the terms and conditions of the Creative Commons Attribution license (http://creativecommons.org/licenses/by/4.0/). 